\title{
Plasma progesterone and gonadotrophin concentrations and ovarian activity in post-partum dairy cows*
}

\author{
R. Webb†, G. E. Lamming, N. B. Haynes and G. R. Foxcroft \\ Department of Physiology and Environmental Studies, University of Nottingham \\ School of Agriculture, Sutton Bonington, Loughborough, Leics LE12 5RD, U.K.
}

\begin{abstract}
Summary. Plasma progesterone concentrations in jugular vein blood samples collected every other day after calving from 13 Friesian dairy cows indicated that ovarian cyclic activity was initiated by $16.6 \pm 1 \cdot 1$ (s.e.m.) days post partum, except for 1 cow which did not resume cyclic activity until Day 98 post partum. Rectal palpation of the ovaries indicated that a developing follicle was recognizable at a mean time of $15.7 \pm 2.0$ days after calving. During the first oestrous cycle after parturition there was a significantly shorter period when plasma progesterone levels were elevated than during the next 2 cycles. Concentrations of progesterone, LH, FSH and prolactin were determined for 4 cows, in blood samples taken every $6 \mathrm{~h}$ from 2 to 36 days post partum. Tonic LH release was lower during the first 10 days than subsequently, but the lack of change in pattern for FSH suggests dissimilar control mechanisms for these hormones during this time. Three cows showed evidence of a resumption of ovarian cyclicity during the sampling period: in 2 there was an initial LH surge of a magnitude which would normally give rise to ovulation, followed 4 days later by an increase in plasma progesterone lasting only 5 and 9 days. This progesterone was considered to be of follicular origin. A second LH surge was followed by the presence of a corpus luteum.
\end{abstract}

\section{Introduction}

It is important for optimal reproductive efficiency in cows that they should calve at 12 -month intervals. This requires that the animals are pregnant by 80 days after calving. Since the level of fertility improves if cows are mated at the second or third ovulation compared to the first (Whitmore, Tyler \& Casida, 1974), it is desirable that ovarian activity is initiated as early as possible post partum. Dairy cows usually experience post-partum ovulation around $20-45$ days after calving and exhibit post-partum oestrus around 30-72 days (Casida et al., 1968; Hurnik, King \& Robertson, 1975; King, Hurnik \& Robertson, 1976), although some, about 7.0\%, show lack of ovarian function for periods considerably longer than this (Lamming \& Bulman, 1976). By comparison, the post-partum interval to ovulation in suckled beef cows is considerably longer; the average period to the first of regular increases in progesterone was $69.7 \pm 12.0$ days in the studies of Webb, Lamming, Haynes, Hafs \& Manns (1977). It would be advantageous, therefore, to have detailed information on reproductive hormone concentrations in the blood of post-partum cows in order to define the circumstances in which an early return of ovarian cycles after parturition is achieved. The interpretation of data from previous investigations (see

* Reprint requests to Professor G. E. Lamming.

$\dagger$ Present address: Nuffield Department of Obstetrics and Gynaecology, John Radcliffe Hospital, Headington, Oxford OX3 9DU, U.K. 
'Discussion' for references) is often difficult because of the variety of blood sampling regimens used and, at the time our work was started, there were to our knowledge no reports on concentrations of blood FSH, a potentially important hormone in initiating reproductive activity. The aim of the present studies was to characterize the hormone changes that occur around the time of initiation of ovarian cyclic activity in the post-partum dairy cow and relate these hormone profiles with changes in ovarian structure as determined by rectal palpation.

\section{Materials and Methods}

\section{Experimental design and collection of blood samples}

Experiment 1. Thirteen (13) second-calved Friesian dairy cows, calving between 30 September and 1 December, were housed in a double-stall cowshed with lights on between 06:00 and 21:00 h and milked first on the afternoon following calving, with the calves being removed from their dams $24 \mathrm{~h}$ after birth. Daily milking took place at 06:00 and 16:00 $\mathrm{h}$ and the cows were turned out onto a concrete yard every day from approximately 09:00 to 10:30 h. A concentrate ration was given at each milking and forage at 12:00 and 21:00 h. The ovaries were palpated per rectum every 7 days by a veterinary surgeon experienced at using this technique. Palpable structures were designated as follicles (small, medium or large), cystic follicles or corpora lutea (see Arthur, 1964). Discharge of mucus from the vulva was taken as an indication of oestrus with cows recorded as 'oestrous' if they stood to be mounted by other cows during the exercise period. Blood samples for plasma progesterone determinations were taken every other day by jugular venepuncture and collection into heparinized tubes between 09:30 and 10:00 h, from calving to 90 days post partum. These samples were centrifuged at $4^{\circ} \mathrm{C}$ and $1600 \mathrm{~g}$ for 15 min within $1 \mathrm{~h}$ of collection and the plasma was stored at $-20^{\circ} \mathrm{C}$ until assayed.

Experiment 2. Four (4) Friesian dairy cows which calved in late October were kept under the same management conditions and underwent rectal palpation as described in the previous experiment. Cows were fitted with an indwelling jugular vein cannula 2 days after calving and blood samples were collected into heparinized tubes every $6 \mathrm{~h}$ for 32 days starting at $06: 00 \mathrm{~h}$. The samples were treated as described for Exp. 1, and subsequently assayed for LH, FSH, prolactin and progesterone content.

\section{Progesterone and LH assays}

Plasma progesterone and $\mathrm{LH}$ were measured by radioimmunoassays used routinely in this laboratory and the assay reliability criteria did not differ significantly from those described by Webb et al. (1977). The intra-assay coefficients of variation (CV) for LH assays, calculated by the method of Snedecor (1952), were $7 \cdot 1 \%$ for values $<10 \mathrm{ng} / \mathrm{ml}$ and $8.3 \%$ for values $>10$ $\mathrm{ng} / \mathrm{ml}$. The inter-assay CV was $12.7 \%$. For progesterone assays, the intra-assay CVs were $4.8 \%$ for values $<4 \mathrm{ng} / \mathrm{ml}$ and $13 \cdot 2 \%$ for values $>4 \mathrm{ng} / \mathrm{ml}$. The inter-assay CV was $12 \cdot 1 \%$.

\section{FSH assay}

Procedure. The antiserum (M94) made available for these studies was raised in rabbits against the human FSH preparation CPD 5/6 (for production details see Lynch \& Shirley, 1975). Rat FSH (NIAMD-Rat FSH-I-3) was iodinated by a modification of the chloramine-T method of Greenwood, Hunter \& Glover (1963) to an approximate specific activity of 80 $\mu \mathrm{Ci} / \mu \mathrm{g}$. A $2 \mu \mathrm{g}$ aliquot of rat $\mathrm{FSH}$ was iodinated in the presence of $0.5 \mathrm{mCi} \mathrm{Na}{ }^{125} \mathrm{I}$ (Amersham) and $10 \mu \mathrm{l}$ chloramine-T solution $(1.5 \mathrm{mg} / \mathrm{ml})$ for $10 \mathrm{sec}$ and the reaction was stopped by adding $100 \mu \mathrm{l}$ sodium metabisulphite $(0.6 \mathrm{mg} / \mathrm{ml})$. Hormone labelled with ${ }^{125} \mathrm{I}$ was separated by column chromatography on Sephadex-G50 and appropriate dilutions of this material were used in the assays without further purification. NIH-FSH-B1 was used as the assay standard. A 
solution of $0.01 \mathrm{M}$-sodium phosphate buffer, $\mathrm{pH} 7.0$, containing $0.14 \mathrm{M}$ - $\mathrm{NaCl}, 0.05 \mathrm{M}$-EDTA, $1.0 \%$ egg white and $0.01 \%$ merthiolate was used as assay diluent. Antiserum (M94) was diluted in the assay diluent containing normal rabbit serum $(1: 400 \mathrm{v} / \mathrm{v})$. All incubations and centrifugations were carried out at $4^{\circ} \mathrm{C}$. The antiserum was tested for total binding activity in the absence of unlabelled antigen by taking serial dilutions from a 1:1000 concentration and adding $50 \mu$ of each dilution to $125 \mu$ lassay diluent. Rat FSH labelled with iodine $(50 \mu l)$ was then added and the mixture was incubated for $24 \mathrm{~h}$. The bound fraction was precipitated by adding $100 \mu \mathrm{l}$ donkey anti-rabbit $\gamma$-globulin (Wellcome, RD17) at a dilution of $1: 10$, incubating for $48 \mathrm{~h}$ and, after adding $1 \mathrm{ml}$ buffer, separating by centrifugation at $4000 \mathrm{~g}$ for 30 min and aspirating the unbound fraction. The final assay procedure was as follows. Standard solutions or plasma were made up to $125 \mu \mathrm{l}$ with assay diluent and then $50 \mu \mathrm{l}$ antiserum at $1: 45000$ dilution were added and the tubes incubated for $48 \mathrm{~h}$. After addition of $50 \mu \mathrm{l}$ ${ }^{125}$ I-labelled rat FSH (approx. 10000 c.p.m.) and a further $48 \mathrm{~h}$ incubation, the bound and free fractions were separated as above but using $100 \mu \mathrm{l}$ of a 1:16 dilution of anti-rabbit $\gamma$-globulin raised in a mature ram kept locally.

Validation. Antiserum M94 bound 20-25\% ${ }^{125} \mathrm{I}$-labelled rat FSH at a dilution of 1:45000 ( $50 \mu \mathrm{l}$ of $1: 10000$ dilution in a final assay volume of $225 \mu \mathrm{l}$ ) and this dilution was used throughout. Sensitivity, defined as the inhibition curve value at twice the s.d. below the mean inhibition in the absence of unlabelled antigen, was $3 \mathrm{ng} /$ tube. For an assessment of accuracy, known amounts (from 1 to $64 \mathrm{ng}$ ) of NIH-FSH-B-1 were assayed after addition of $50 \mu \mathrm{l}$ plasma from pooled material from late pregnant cows. After adjustment for the $55 \mathrm{ng} \mathrm{FSH} / \mathrm{ml}$ measured in this pool, the mean recovery figure was $103.3 \pm 2.6 \%$ (see Text-fig. 1 for values at particular concentrations of added FSH). Cross-reactions were calculated as the amount of other hormones (w/w with FSH) giving $50 \%$ inhibition in the assay and were $3 \cdot 2 \%$ for bovine TSH and $0.3 \%$ for bovine $\mathbf{L H}$. Values for prolactin and growth hormone were $<0.2 \%$. Inhibition curves for 3 plasma samples measured at different dilutions shows parallelism to the standard curve (see Text-fig. 1). The inter-assay CVs (4 assays) over the ranges $30-60 \%$ and $60-85 \%$ bound were 10.0 and $13.3 \%$ respectively. The intra-assay CV for randomly selected duplicate pairs was $9 \cdot 8 \%(n=20)$.

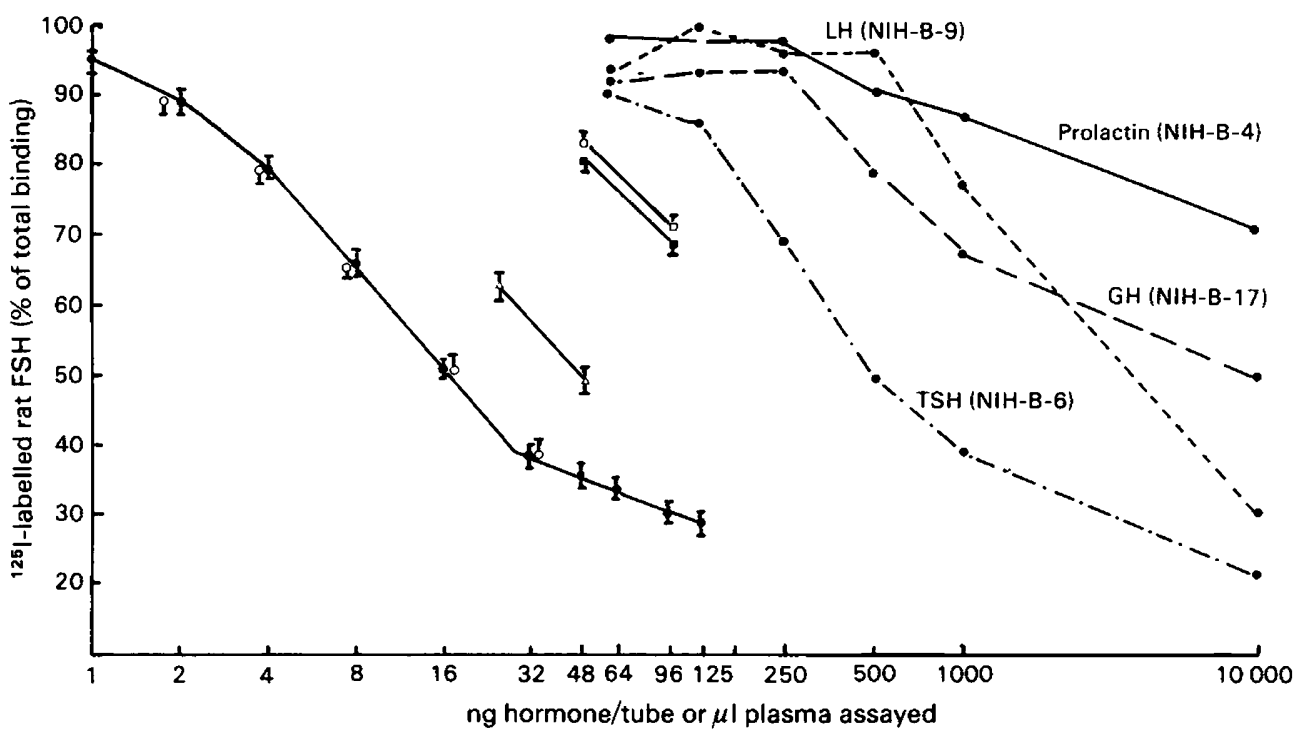

Text-fig. 1. Mean ( \pm s.e.m.) values for the standard curve, cross-reactivity and parallelism in the FSH assay. $O$, values for standard curve points with $50 \mu$ plasma from late pregnant cows and after correction for estimated endogenous FSH; $\square$, cow plasma pool 1; $\mathbf{\square}$, cow plasma pool 2; $\Delta$, bullock plasma. There were $12-21$ observations at each point. 
$R$. Webb et al.

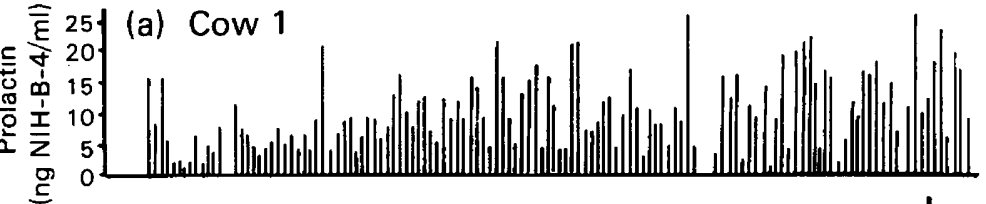
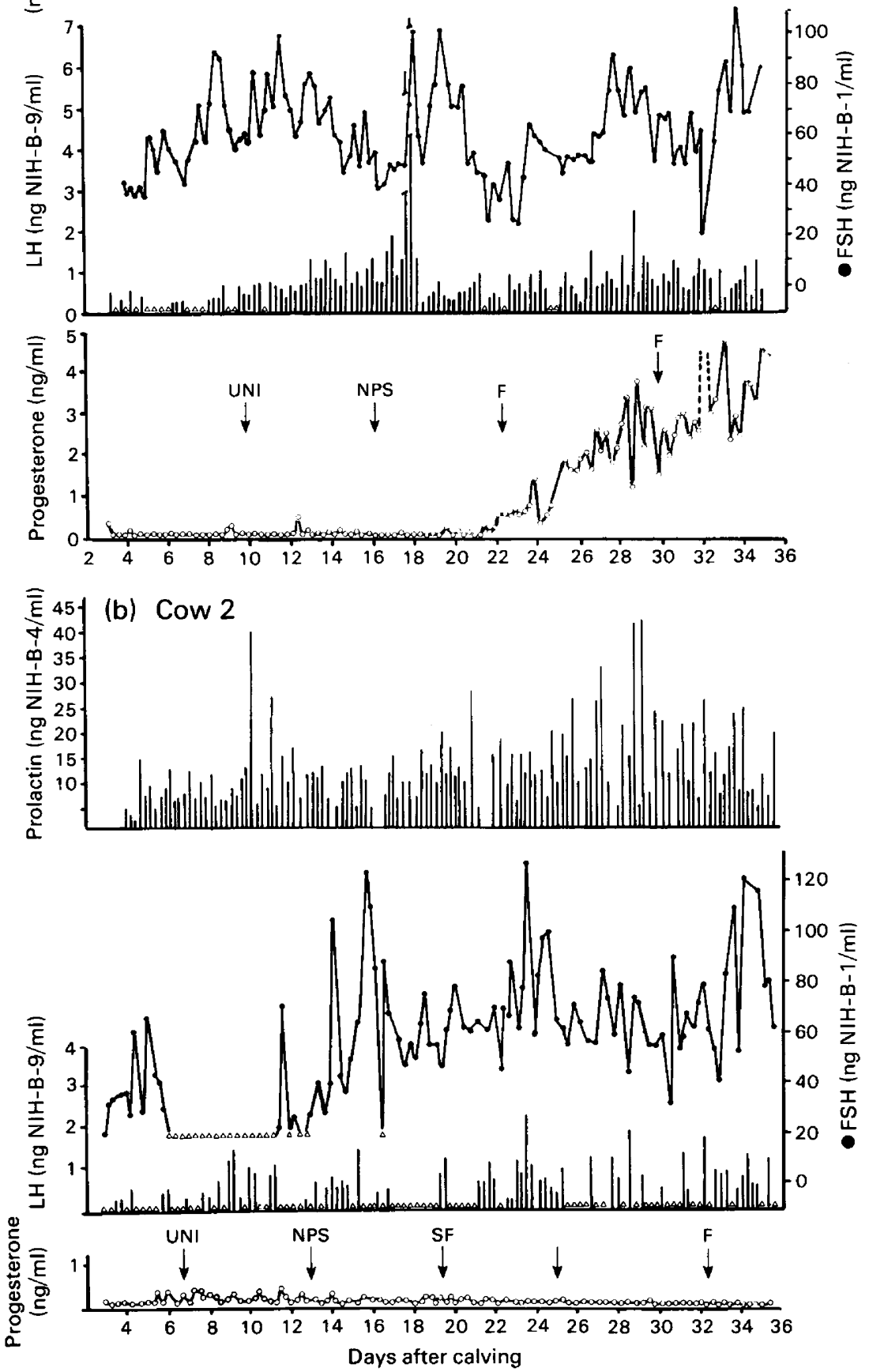

Text-fig. 2. Changes in hormone concentrations in Cows 1(a), 2(b), 3(c) and 4(d). Concentrations indicated by $\triangle$ were below the sensitivity of the particular assay. UNI, uterus not involuted; NPS, no palpable structure; SF, small follicle; F = large follicle; CL, corpus luteum; OC, ovarian cyst. Cow 2 did not ovulate. 
$\left.={ }^{40} 35\right]$ (c) Cow 3

ind
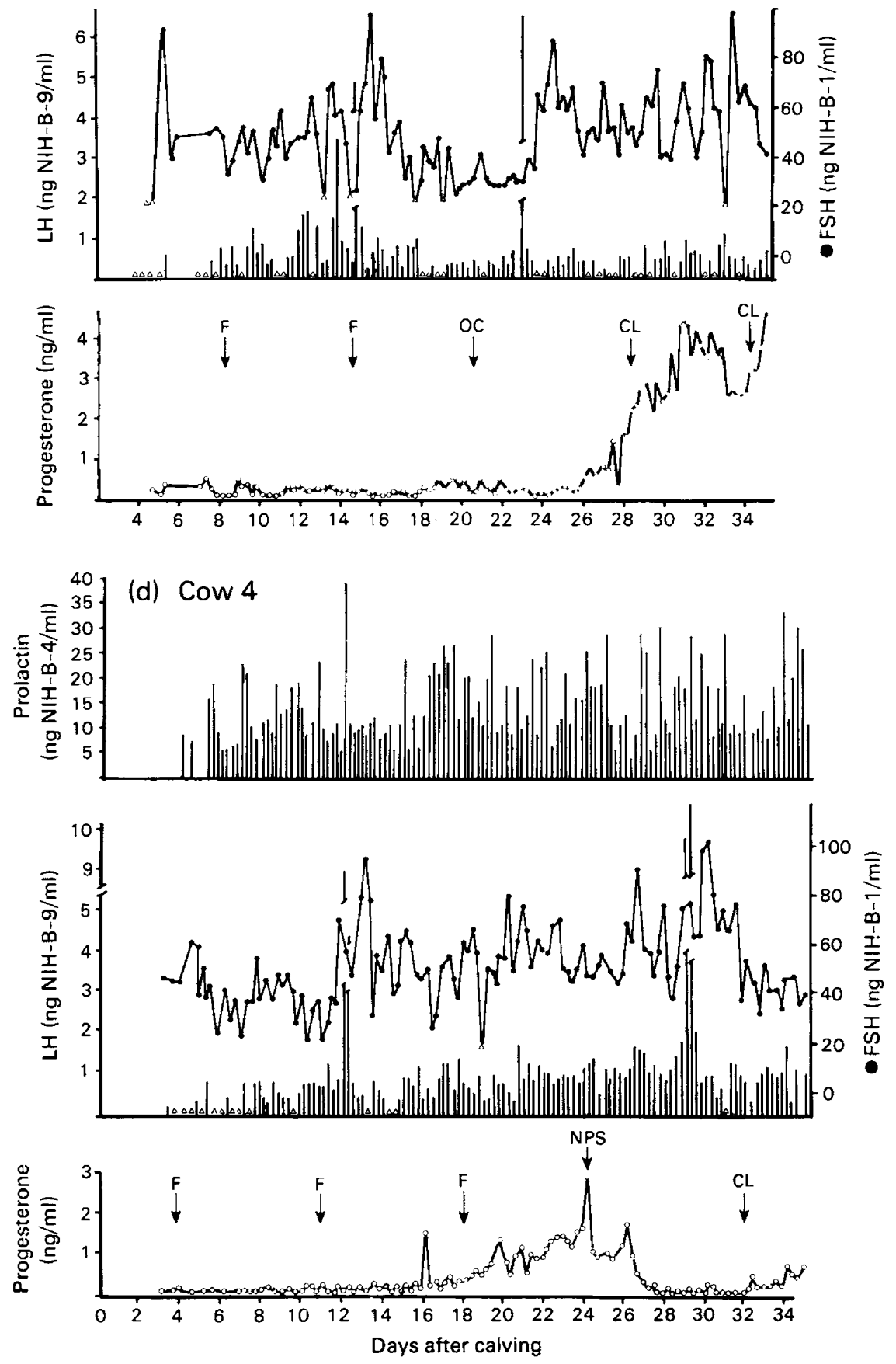


\section{Prolactin assay}

Procedure. Antiserum was raised in mature New Zealand White rabbits. This was accomplished by subcutaneous injection of $1 \mathrm{mg} \mathrm{NIH-P-B3}$ emulsified in $0.5 \mathrm{ml} 0.154 \mathrm{M}$ $\mathrm{NaCl}$ and $0.5 \mathrm{ml}$ Freund's complete adjuvant. The injections were given at several sites and repeated weekly for 6 weeks. Finally, 2 booster injections were given at 1-month intervals and 14 days later blood was collected, and the serum stored at $-20^{\circ} \mathrm{C}$. Iodination of NIH-P-B3 was carried out to an approximate specific activity of $80 \mu \mathrm{Ci} / \mu \mathrm{g}$ as described for FSH but with two purification steps by column chromatography, firstly on Sephadex-G20 and then SephadexG100. A solution of $0.05 \mathrm{M}$-sodium phosphate buffer, $\mathrm{pH} 7.0$, containing $0.14 \mathrm{M}-\mathrm{NaCl}, 0.05$ M-EDTA, $1.0 \%$ bovine serum albumin, $0.08 \%$ normal rabbit serum and $0.01 \%$ merthiolate was used as the assay diluent. The assay procedure was as described for FSH with the following modifications. Standard solutions were made up to $500 \mu \mathrm{l}$ with diluent and $200 \mu \mathrm{l}$ antiserum at an actual dilution of 1:40000 and $200 \mu \mathrm{l}{ }^{125}$ I-labelled prolactin (containing approximately 20000 c.p.m.) were added. The second antibody was $200 \mu \mathrm{l}$ of a $1: 40$ dilution of anti-rabbit $\gamma$-globulin raised in a wether. At each of the three stages the incubation time was $24 \mathrm{~h}$.

Validation. Antiserum from one rabbit bound $40-50 \%{ }^{123}$ I-labelled rat prolactin at a dilution of $1: 40000$ and this dilution was used throughout. Sensitivity was $50 \mathrm{pg} /$ tube. Accuracy was assessed by running standard curves for prolactin in buffer and the same amounts of prolactin added to hypophysectomized sheep plasma. The curves were superimposable. Inhibition curves for plasma samples of 3 cows at dilutions from 1:2.5 to $1: 80$ were parallel to the prolactin standard curve. The antiserum showed $<0.5 \%$ inhibition when tested against the bovine hormone preparations NIH-GH-B17, NIH-LH-B9, NIH-FSH-B1 and NIH-TSH-B6. The interassay CVs (6 assays) in 3 standard plasma samples was $14.1 \%$. The intra-assay CV for 20 randomly selected duplicate pairs was $5.3 \%$ for values $<20 \mathrm{ng} / \mathrm{ml}$ and $6.0 \%$ for values $>20$ $\mathrm{ng} / \mathrm{ml}$.

\section{Results}

\section{Experiment 1}

Rectal palpations indicated the presence of ovarian follicles by a mean ( \pm s.e.m.) time of 15.7 \pm 2.0 days after calving; however 4 of the 13 cows had small follicles at the first palpation per rectum carried out after calving (4, 7,9 and 9 days post partum respectively).

Regular cyclic activity, assessed by the appearance of increased plasma progesterone concentrations, was initiated by $16.6 \pm 1 \cdot 1$ (s.e.m.) days after calving, except for one cow which just showed signs of oestrus at Day 98 post partum, was artificially inseminated and became

Table 1. Mean ( \pm s.e.m.) oestrous cycle lengths and duration of elevated plasma progesterone from 12 post-partum cows (Exp. 1)

\begin{tabular}{lccc}
\hline & First cycle & Second cycle & Third cycle \\
\hline $\begin{array}{l}\text { Oestrous cycle length } \\
\text { (days) }\end{array}$ & $14.9 \pm 1.4$ & $20.8 \pm 0.6$ & $21.0 \pm 0.6$ \\
$\begin{array}{c}\text { Duration of elevated plasma } \\
\text { progesterone (days) }\end{array}$ & $9.6 \pm 1.0^{\mathrm{ab}}$ & $13.0 \pm 0.7^{\mathrm{a}}$ & $12.4 \pm 0.5^{\mathrm{b}}$ \\
$\begin{array}{c}\text { Peak concentration of plasma } \\
\text { progesterone (ng/ml) }\end{array}$ & $4.4 \pm 0.8^{\mathrm{c}}$ & $5.6 \pm 0.4$ & $5.8 \pm 0.7^{\mathrm{c}}$ \\
\hline
\end{tabular}

Initiation of ovarian cyclic activity was taken as the first increase in progesterone concentrations greater than the mean $+2 \times$ s.d. of the previous basal values.

Statistical analysis was carried out using analysis of variance for a randomized block design in conjunction with Duncan's new Multiple Range Test (1955), using the critical values calculated by Harter (1960): values with similar superscripts were significantly different $(P<0 \cdot 05)$. 
pregnant. During the first oestrous cycle after parturition there was a significantly shorter period when plasma progesterone was elevated than during the second or the third oestrous cycles, with 7 out of 12 cows having first oestrous cycle lengths of $<16$ days. Progesterone peak height was not significantly different in the first and second cycles, but that in the first was significantly lower than that in the third oestrous cycle (Table 1).

\section{Experiment 2}

Plasma hormone concentrations for each of the 4 cows are illustrated in Text-fig. 2.

Plasma progesterone levels and ovarian palpation data. Plasma progesterone concentration remained low in Cow 1 (Text-fig. 2a) until 4 days after an LH surge on Day 18 post partum, and then increased and fluctuated at levels $>2.5 \mathrm{ng} / \mathrm{ml}$ until the end of the sampling period. A large follicle, but no corpus luteum, was palpable on the right ovary during this time: the left ovary was not examined because of difficulties locating it during palpation. In Cow 2 (Text-fig. 2b), plasma progesterone remained low throughout, although follicular development was detectable by palpation. Progesterone concentrations in Cow 3 (Text-fig. 2c) were low until Day 18, 4 days after an LH surge, and then reached $0.5 \mathrm{ng} / \mathrm{ml}$. Between Days 18 and 22, 6 blood samples had progesterone concentrations greater than the mean $+2 \times$ s.d. of the value in samples taken from Days 10 to 18 . Levels had fallen to $<0.2 \mathrm{ng} / \mathrm{ml}$ by Day 23 but increased to $>2 \mathrm{ng} / \mathrm{ml}$ after Day 18. An ovarian cyst was identified at palpation about Day 20 and the elevation from Day 28 was associated with a corpus luteum. Plasma progesterone was characterized in Cow 4 (Text-fig. 2d)

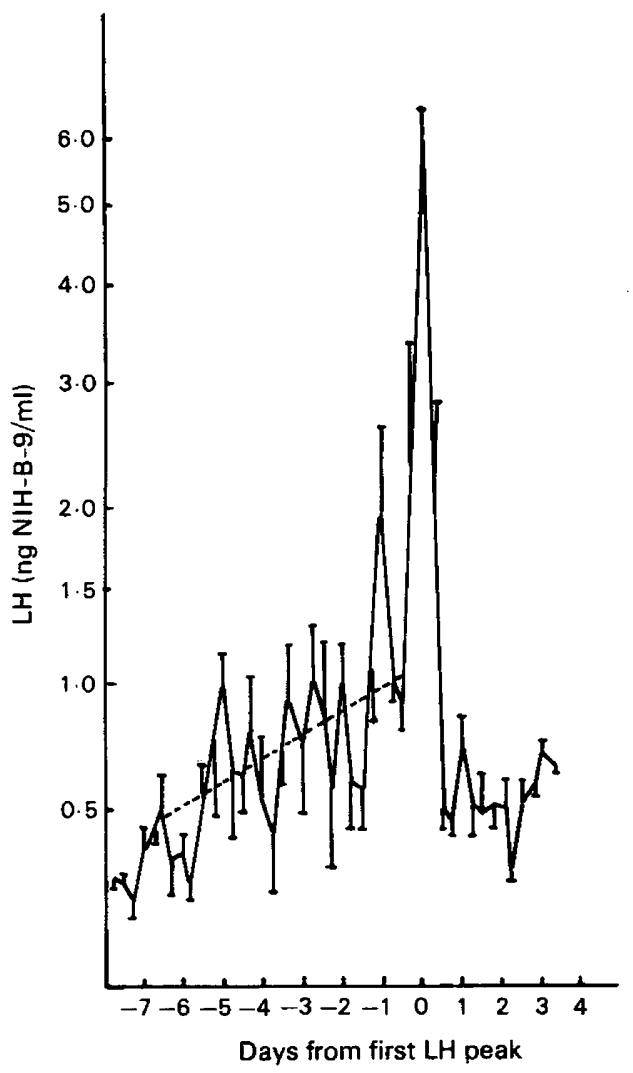

Text-fig. 3. Mean plasma LH concentrations (+ or - s.e.m.) normalized to the first LH peak of ovulatory magnitude in Cows 1,3 and 4 post partum. The regression equation for the change marked by the broken line is $y=1.15-0.11 x, r=0.46(n=90 ; P<0.001)$. 
by a 9-day elevation (reaching $3 \mathrm{ng} / \mathrm{ml}$ ) between Days 17 and 26 and a second rise beginning on Day 34. A large follicle was present during the first rise and a corpus luteum during the second.

$L H$. Episodic LH secretion was evident throughout the sampling period. The amplitude of the episodes increased gradually in all cows until about Day 10. After this, tonic episodic release in 3 of the cows was interspersed with LH surges comparable to those which initiate ovulation during the cycle (Schams, Schallenberger, Hoffmann \& Karg, 1977), i.e. on Day 18 in Cow 1, Days 14 (a double peak) and 23 in Cow 3, and Days 12 and 29 in Cow 4. Cow 2, which had no LH peaks of surge magnitude, had markedly more LH measurements below the sensitivity of the assay than than did the other cows. Pronounced surges of LH occurred only when progesterone concentrations were low but the magnitude of tonic $\mathrm{LH}$ secretion was not related to the level of progesterone. There tended to be an increase in the baseline concentration of plasma LH from 6 days before an LH surge, but LH decreased to basal concentrations immediately after the surge (Text-fig. 3).

FSH. Concentrations of this hormone showed marked fluctuations. Peaks were observed concomitant with an LH surge but peaks of similar magnitude occurred at other times. FSH concentration during the first 15 days post partum in Cows 2 and $4(28.4 \pm 2.7$ and $47.4 \pm 2.7$ $\mathrm{ng} / \mathrm{ml}$ respectively) was significantly lower $(P<0.01$; Students' $t$ test for unpaired data) than subsequently $(69.9 \pm 2.3$ and $55.0 \pm 1.6 \mathrm{ng} / \mathrm{ml}$ respectively). This difference was not found in Cows 1 and 3. FSH concentrations were not correlated with progesterone levels.

Prolactin. Mean concentrations over the whole sampling period were $9.8 \pm 0.51,12.0 \pm$ $0.71,12.5 \pm 0.62$ and $15.2 \pm 0.67 \mathrm{ng} / \mathrm{ml}$ for Cows $1-4$ respectively. The difference between Cow 1 and 4 is significant $(P<0.01$ : analysis of variance). Specific fluctuations could not be associated with particular changes in concentration of other hormones and the levels in the non-cyclic Cow 2 were not significantly different from those in the cows which showed cyclic activity.

\section{Discussion}

The evidence that is accumulating in relation to changes in blood plasma hormone levels in post-partum cows is providing a progressively more accurate picture of the endocrine changes which normally occur when cows return to full ovarian cyclicity. This will permit better interpretation of the differences in oestrous behaviour and the interval to first ovulation observed between different breeds and within breeds according to whether the animals are suckling or milked. It will also assist the development of efficacious hormone treatments for animals in which there is a delay in the initiation of ovarian changes leading to mating and conception. Although the mechanism by which suckling delays the first ovulation is still not clear, the endocrine events leading to the initiation of first ovulation in milked and suckled cows are similar (Lamming, 1978) and in most animals the first complete ovarian cycle is preceded by a short period of elevated plasma progesterone. The short-term elevation in plasma progesterone (Table 1) which occurred in 7 out of 12 cows in Exp. 1 and in Cows 3 and 4 in Exp. 2 and preceded the onset of normal ovarian and oestrous cycles has been previously noted by a number of workers (Pope, Gupta \& Munro, 1969; Donaldson, Bassett \& Thorburn, 1970; Robertson, 1972; Tribble et al., 1973; Lamming \& Bulman, 1976). The origin of this transient increase in peripheral plasma progesterone is not known, although it has been previously suggested that it originates from luteinized follicles (Tribble et al., 1973). The results reported here indicate that there is an LH surge before the elevation of plasma progesterone above basal concentrations during the post-partum period in the dairy cow. The time relationship between the occurrence of this LH surge and the increase in progesterone (4-5 days) is similar to that in the normal cycle (Schams et al., 1977) and supports the view that this progesterone comes from the ovary; developing follicles are the most likely source because no corpora lutea were palpated at this time. 
Once normal ovarian activity had been initiated the increase in progesterone per se did not appear to affect the tonic $\mathrm{LH}$ release pattern in the cows in Exp. 2. However, there is evidence of a negative feedback influence of progesterone on tonic $\mathrm{LH}$ release in the ewe (Karsch, Legan, Hauger \& Foster, 1977; Hauger, Karsch \& Foster, 1977) and this possible effect needs to be investigated in more detail in the cow. In the present study an LH surge never occurred when progesterone was elevated. Large follicles were present at this time and progesterone may prevent surge release of LH by inhibiting the positive feedback of follicular oestrogen as found for ewes (see review by Baird, Baker, McNatty \& Neal, 1975). Administration of exogenous progesterone in the cow blocks oestrus and ovulation (Ulberg, Christian \& Casida, 1951; Roche, 1974). Withdrawal of progesterone is followed by a return to oestrus and ovulation. The hypothalamus and/or pituitary must, however, be sensitive to small changes in progesterone concentrations because in Cow 3 (Exp. 2) there was a change in progesterone concentration of only $0.3 \mathrm{ng} / \mathrm{ml}$ which was presumably sufficient to prevent an ovulatory LH surge.

The gradual increase in tonic $\mathrm{LH}$ release from calving to around Day 10 post partum, similar to that reported by Echternkamp \& Hansel (1973), Kesler, Garverick, Youngquist, Elmore \& Bierschwal (1977) and Goodale et al. (1978), may be directly related to the removal of an inhibitory effect of the previous pregnancy on pituitary LH content since an increase in pituitary LH concentration from parturition until 20-30 days post partum has been demonstrated (Wagner, Saatman \& Hansel, 1969). Furthermore, in dairy cows there is an increased pituitary response in terms of $\mathrm{LH}$ release to synthetic $\mathrm{Gn}-\mathrm{RH}$ by 10 days post partum compared to 5 days (Kesler et al., 1977; Lamming, 1978). Further evidence that an early increase in basal LH may be an important feature in initiation of ovarian cyclicity post partum has recently been obtained. Sampling at 10-min intervals showed that suckled dairy cows, which have a longer post-partum anoestrous period, have lower plasma LH concentrations than milked dairy cows during the first 20 days post partum. This is due to a combination of a different pulsatile release pattern and a lower basal LH concentration (G. E. Lamming, A. R. Peters \& S. Vyvoda, unpublished observations). Additionally, Cow 2 (Exp. 2), which could be considered abnormal on the basis that 12 similar cows in Exp. 1 had increased plasma progesterone levels by $16.6 \pm 1 \cdot 1$ days after calving, had an LH profile different from that of the other cows in Exp. 2.

As shown in Text-fig. 3 there was an increase in the basal concentrations of LH for a few days before the first surge of $\mathbf{L H}$ which preceded the short-term elevation of progesterone or the first full ovarian cycle. This earlier increased LH release has been previously demonstrated in cows (Chenault, Thatcher, Kalra, Abrams \& Wilcox, 1975). Furthermore, Shemesh \& Hansel (1975) found increased oestradiol production in vitro by 16- or 17-day cow follicles after stimulation with LH. Palpation data in Exp. 1 indicated ovarian follicular activity before the start of oestrous cycle activity. The triggering of the first LH surge which appears an important event in the establishment of ovarian cycles post partum may therefore be a positive feedback response to follicular oestradiol. A significant positive correlation between increasing $\mathrm{LH}$ and oestradiol before the preovulatory LH surge in sheep lends support to this hypothesis (Hauger et al., 1977).

For the increase in LH to be the mechanism which triggers the initiation of oestrous cycle activity, follicles capable of responding to increased tonic LH release would have to be present and the role of FSH in the induction of follicular growth cannot be ignored. The fluctuating FSH concentrations found in all 4 cows in Exp. 2 were of a magnitude similar to that reported by Dobson (1978a, b). Cow 2, which did not start cycling during the sampling period, had lower FSH concentrations than the others during the first 15 days post partum, but there were otherwise no significant differences in plasma FSH between animals. This, and the lack of obvious correlation between plasma FSH and other endocrine events, indicates that changes in plasma FSH are not critical for the initiation of the first ovarian cycle. A decline in FSH concomitant with ovarian cyclicity noted by Dobson (1978a) was not observed, although a complete 
progesterone cycle was not followed in the current study. The fact that FSH values are relatively high at the start of the sampling period and do not always show an increase at the same times as $\mathrm{LH}$ rises suggests that dissimilar control mechanisms exist for the release of the two hormones during this period. During preparation of this manuscript Schams et al. (1978) reported a similar experiment with essentially the same conclusions concerning the status of progesterone, $\mathrm{LH}$ and FSH in the plasma of post-partum dairy cows.

Plasma prolactin concentrations in the present study were equivalent to those found by Ingalls, Convey \& Hafs (1973), but did not show the gradual decline from Day 9 to Day 26 that they reported. The fact that Cow 2 which did not show cyclic activity by Day 36 post partum had prolactin levels similar to those in Cow 3 and intermediate between those of Cows 1 and 4 suggests that hyperprolactinaemia was not responsible for the lengthened post-partum interval, contrary to suggestions for other species (Rolland, Lequin, Schellekens \& de Jong, 1975; Kann, Martinet \& Schirar, 1978).

We thank Miss C. Ford for the rectal palpations; Dr H. Swan and Mr C. Mills who developed and carried out the prolactin assay and allowed us to publish reliability data; Professor H. D. Hafs, Professor W. R. Butt and Dr B. J. A. Furr for providing the LH, FSH and progesterone antisera respectively; NIH for supplying hormone preparations; and $\mathrm{Dr} \mathrm{L}$. E. Reichert, Jr for the purified LH (LER-1072-2). One of us (R.W.) received a Meat and Livestock Commission Grant and the Agricultural Research Council also provided financial support.

\section{References}

Arthur, G.H. (1964) Wright's Veterinary Obstetrics, 3rd edn, pp. 354-390. Balliere, Tindall \& Cox, London.

Baird, D.T., Baker, T.G., McNatty, K.P. \& Neal, P. (1975) Relationship between secretion of the corpus luteum and the length of the follicular phase of the ovarian cycle. J. Reprod. Fert. 45, 611-619.

Casida, L.E., Graves, W.E., Hauser, E.R., Lauderdale, J.W., Reisen, J.W., Saiduddin, S. \& Tyler, W.J. (1968) Studies on the post-partum cow. Bull. Wis. agric. Exp. Stn 270, 1-54.

Chenault, J.R., Thatcher, W.w., Kalra, P.S., Abrams, R.M. \& Wilcox, C.J. (1975) Transitory changes in plasma progestins, estradiol and luteinizing hormone approaching ovulation in the bovine. J. Dairy Sci. 58, $709-717$.

Dobson, H. (1978a) Radioimmunoassay of FSH in the plasma of post-partum dairy cows. J. Reprod. Fert. 52, 45-49.

Dobson, H. (1978b) Plasma gonadotrophins and oestradiol during oestrus in the cow. J. Reprod. Fert. 52, 51-53.

Donaldson, L.E., Bassett, J.M. \& Thorburn, G.D. (1970) Peripheral plasma progesterone concentration of cows during puberty, oestrous cycles, pregnancy and lactation, and the effects of undernutrition or exogenous oxytocin on progesterone concentration. J. Endocr. 48, 599-614.

Duncan, D.B. (1955) Multiple range and multiple F tests. Biometrics 11, 1-42.

Echternkamp, S.E. \& Hansel, W. (1973) Concurrent changes in bovine plasma hormone levels prior to and during the first post-partum estrous cycle. $J$. Anim. Sci. 37, 1362-1370.
Greenwood, F.C., Hunter, W.M. \& Glover, J.S. (1963) The preparation of ${ }^{131}$ I-labelled human growth hormone of high specific radioactivity. Biochem. $J$. 89, 114-123.

Goodale, W.S., Garverick, H.A., Kesler, D.J., Bierschwal, C.J., Elmore, R.G. \& Youngquist, R.S. (1978) Transitory changes in hormones in plasma of post-partum dairy cows. J. Dairy Sci. 61, 740-746.

Harter, H.L. (1960) Critical values for Duncans new multiple range test. Biometrics 16, 671-685.

Hauger, R.L., Karsch, FJ. \& Foster, D.L. (1977) A new concept for control of the estrous cycle of the ewe based on the temporal relationships between luteinizing hormone, estradiol, and progesterone in peripheral serum and evidence that progesterone inhibits tonic LH secretion. Endocrinology 101, 807-817.

Hurnik, J.F., King, G.F. \& Roberton, H.A. (1975) Estrus and related behaviour in post-partum Holstein cows. Appl. Anim. Ethol. 2, 55-62.

Ingalls, W.G., Convey, E.M. \& Hafs, H.D. (1973) Bovine serum $\mathrm{LH}, \mathrm{GH}$ and prolactin during late pregnancy, parturition and early lactation. Proc. Soc. exp. Biol. Med. 143, 161-164.

Kann, G., Martinet, J. \& Schirar, A. (1978) Hypothalamic-pituitary control during lactation in sheep. In Control of Ovulation, pp. 319-333. Eds D. B. Crighton, N. B. Haynes, G. R. Foxcroft \& G. E. Lamming. Butterworths, London.

Karsch, F.J., Legan, S.J., Hauger, R.L. \& Foster, D.L. (1977) Negative feedback action of progesterone on tonic luteinizing hormone secretion in the ewe. Dependence on the ovaries. Endocrinology 101, 800-806. 
Kesler, D.J., Garverick, H.A., Youngquist, R.S., Elmore, R.G. \& Bierschwal, CJ. (1977) Effect of days post partum and endogenous reproductive hormones on Gn-RH-induced LH release in dairy cows. J. Anim. Sci. 46, 797-803.

King, G.J., Hurnik, J.F. \& Robertson, H.A. (1976) Ovarian function and estrus in dairy cows during early lactation. J, A nim. Sci. 42, 688-692.

Lamming, G.E. (1978) Reproduction during lactation. In Control of Ovulation, pp. 335-353. Eds D. B. Crighton, N. B. Haynes, G. R. Foxcroft \& G. E. Lamming. Butterworths, London.

Lamming, G.E. \& Bulman, D.C. (1976) Use of milk progesterone radioimmunoassay in the diagnosis and treatment of subfertility in dairy cows. Br. vet. J. 132, 507-517.

Lynch, S.S. \& Shirley, A. (1975) Production of specific antisera to follicle-stimulating hormone and other hormones. J. Endocr. 65, 127-132.

Pope, G.S., Gupta, S.K. \& Munro, I.B. (1969) Progesterone levels in the systemic plasma of pregnant, cycling and ovariectomized cows. J. Reprod. Fert. 20, 369-381.

Robertson, H.A. (1972) Sequential changes in plasma progesterone in the cow during the estrous cycle, pregnancy, at parturition and post-partum. Can. J. Anim. Sci. 52, 645-658.

Roche, J.F. (1974) Effect of short-term progesterone treatment on oestrous response and fertility in heifers. J. Reprod. Fert. 40, 433-440.

Rolland, R., Lequin, R.M., Schellekens, L.A. \& de Jong, F.H. (1975) Role of prolactin in the restoration of ovarian function during the early post-partum period in the human female. 1. Study during physiological lactation. Clin. Endocr. 4, 15-25.
Schams, D., Schallenberger, E., Hoffmann, B. \& Karg, H. (1977) The oestrous cycle of the cow: Hormonal parameters and time relationships concerning oestrus, ovulation and electrical resistance of the vaginal mucus. Acta endocr., Copenh. 86, 180-192.

Schams, D., Schallenberger, E., Menzer, Ch., Stangl, J., Zottmeier, B., Hoffmann, B. \& Karg, H. (1978) Profiles of LH, FSH and progesterone in postpartum dairy cows and their relationship to the commencement of cyclic functions. Theriogenology 10, 453-468.

Shemesh, M. \& Hansel, W. (1975) Stimulation of follicular steroidogenesis by $\mathrm{PGF}_{2 \alpha}$ and LH. J. Anim. Sci. 41, 379.

Snedecor, G.W. (1952) Query 92. Biometrics 8, 85-86.

Tribble, R.L., Sorensen, A.M., Woodward, T.L., Connor, J.S., Beverly, J.R. \& Fleeger, J.L. (1973) Serum progestins and luteinizing hormone levels in nonsuckled primiparous heifers. Nature, Lond. 246, 494-495.

Ulberg, L.C., Christian, R.E. \& Casida, L.E. (1951) Ovarian response in heifers to progesterone injections. J. Anim. Sci. 10, 752-759.

Wagner, W.C., Saatman, R. \& Hansel, W. (1969) Reproductive physiology of the post-partum cow. II. Pituitary, adrenal and thyroid function. J. Reprod. Fert. 18, 501-508.

Webb, R., Lamming, G.E., Haynes, N.B., Hafs, H.D. \& Manns, J.G. (1977) Response of cyclic and postpartum suckled cows to injections of synthetic LH-RH. J. Reprod. Fert. 50, 203-210.

Whitmore, H.L., Tyler, W.J. \& Casida, L.E. (1974) Effects of early post-partum breeding in dairy cattle. J. Anim. Sci. 38, 339-346.

Received 1 October 1979 